\title{
The Specificity of Professional Learning Communities in Romania
}

\author{
Anca Luștrea`, Mariana Crașovan`
}

\begin{abstract}
Romanian educational system is in a constant search for reform, due to one of the highest rates of students' underachievement in basic skills and lack of qualified teachers among EU member states. It is well established that professional learning communities (PLCS) can be a solution for both problems, aiming to enhance students 'results by teacher collaboration in learning and professional development.

This study aims to determine the specificity of Romanian PLCs in relation with some contextual factors - school size, school environment (urban or rural), type of school (general or special school), professional development procedures at school level, and the individual factors that can impact the $P L C$, represented by teachers ' personality structure. To answer the research question, reflecting on what contextual and individual factors determine the specificity of PLCs, two online questionnaires and a demographic survey were distributed to teachers across Romania. First, the School Professional Staff as Learning Community Questionnaire (SPSLCQ) was validated on the 253 participants, the original five-factor structure of SPSLCQ adequately fit the sample and proved to be a reliable instrument in the Romanian population.

The results showed the Romanian PLCs'do not significantly differ from other countries: the most representative PLC dimension is shared vision, the organizational factor which explains best the PLC is the existence of strong at-school-level professional development procedures. School size best describes the differences between PLCs, but they do not differ in terms of school environment and school type. The personality factor that correlates the most with PLC is conscientiousness, but the correlation is non-significant.

These results suggest that for functionally stronger PLCs, the school should implement professional development procedures at school level, based on collaboration and mutual learning in small groups of teachers.
\end{abstract}

Keywords: professional learning communities, teaching, professional development, SPSLCQ

\section{Introduction}

The main purpose of the study is to determine the characteristics of Romanian professional learning communities (PLCs). In the context in which there is an increased need of qualified teachers combined with one of the highest rates of students underachievement in basic skills among EU countries (European Commission, 2017), we aim to investigate the collaborative professional development practices in Romanian schools.

\footnotetext{
- PhD, Associate Professor, Department of Educational Sciences, University Clinic for Therapies and PsychoPedagogic Counselling, West University of Timisoara, Romania, anca.lustrea@e-uvt.ro

- PhD, Associate Professor, Department of Educational Sciences, West University of Timisoara, Romania, mariana.crasovan@e-uvt.ro
} 
Implementing PLCs has become a definitory feature of school reform (Diehl \& Diehl, 2019). The professional learning communities (PLCs) are an important factor for professional learning and development (Bolam et al., 2005, Stoll, Bolam, McMahon, Wallace \& Thomas, 2006), quality of teaching (Darling-Hammond \& Richardson, 2009; Stewart, 2014; Gore et al., 2017) and positive student's learning outcome (LoucksHorsley \& Matsumoto, 1999; Vescio, Ross \& Adams, 2008; Doppelt et al., 2009; Lomos, Hofman, \& Bosker, 2011; Ratts et al., 2015; Dogan \& Adams, 2018). Also, PLC improve the quality of teachers, for example by helping them to keep their expertise up to date and to improve practices in their schools. (Dogan at all, 2016)

Each organization, including schools, should permanently aim to achieve high quality standards and improved performance. These aims can be achieved through developing and implementing strong PLCs at school level. DuFour (2004) describes three core principles of the PLC: guaranteeing students' learning, establishing a culture of collaboration and focusing on results. Traditional professional development (PD) practices, lecture-based, such as courses and seminars, are teacher-centred, trying to fulfil the teacher`s professional growth needs. Traditional PD practices are formal and unrelated to classroom reality, abstract and followed in an individual manner (Lieberman, 1995). Modern practices, described as "collaborative professionalism" (Hargreaves \& O`Connor, 2018) should focus on collaboration and need to be in direct relation with the classroom and the student`s needs. The direct result of teacher`s PD is indeed the increase of teacher's knowledge and skills, but the true beneficiaries of teacher's PD should be the students (Berry, 2011). So, we can measure the quality of PD by the student's learning outcome and the functional dimension of their learning.

The quality of teachers is not only about fulfilling mandatory professional standards but also about improving quality through continuous professional development (CPD). In Romania the CPD is mainly linked to the formal aspect of compulsory training stages (Dumitriu, Dumitriu, \& Timofte, 2014) that do not specifically nurture a collaborative school-level and student-centred professional development. The collaborative PD practices at school level are represented in Romania by the methodical-scientific and psycho-pedagogical activities carried out at unit level (methodical committees, departments and pedagogical circles) (Eurydice, 2018). These practices often address teachers` needs and not students' learning. PLCs` by their nature address students` learning and collaborative practices among teachers (DuFour, 2004). In their book, Learning by doing, DuFour at all (2016) make a difference between interest and commitment to PLC. Even if a significant number of studies address PLCs, the number of educators that have moved from interest to commitment has not increased. "It is time to move from thinking about PLCs and talking about PLCs to doing what PLCs actually do and getting better at it." (p.3)

The quality of students` learning and their results depend to a significant extent on the continuous PD of teachers and on the standardization of their teaching practices. PLCs can be a solution to this problem, and we aim to investigate it further. 
Our intercession is in line with the PLC research agenda proposed by Hairon, Goh, Chua and Wang (2015), where a research gap in theorization of PLC condition and context was asserted.

In this study we analyse some contextual factors that can influence the functioning of the PLC: school size, school environment (urban or rural), type of school (general or special school), and professional development procedures at school level. Also, we take into consideration the individual factors that can impact the PLC, represented by the teachers` personality structure.

\section{Theoretical background}

The idea of professional learning community first appeared in the USA in the 1960s but the its' conceptualization was crystalized in the 1990s along with the contributions of Hord (1997), Dufour and Eaker (1998).

The concept of PLC has various definitions but mainly refers to "inclusive and mutually supportive group of people with a collaborative, reflective, and growth-oriented approach toward investigating and learning more about their practice in order to improve students' learning " (Stoll, 2010, p.151).

Doğan and Adams (2018) report five common traits in PLC definitions across scientific literature: emphasis on collaboration, shared vison and purpose, focus on student learning, reflective dialogue and support conditions to make teacher`s work public.

Our research is based on Hord's (1997) view on the PLC. She identified five main characteristics of PLCs: supportive and shared leadership, collective creativity, shared values and vision, supportive conditions and shared personal practice. Collaboration is the main aspect of the PLC. Collaboration takes place both at school level through shared leadership, shared vision and creating supportive conditions and at an individual level by collective creativity and peer-review. The fundamental purpose of teamwork is studentcentred, aiming to grow the students` learning outcome. In this context, it is known that although the teaching profession is one of the most sociable based on multiple interactions with students, colleagues, parents, and the community as a whole, it is one of the most solitary professions. Most of the time, teachers design instruction, teach and assess alone.

Hairon et al. (2015) have identified three main directions in PLC research: defining the construct, studying the PLC context and determining its effects. Our research is embedded in the PLC context research framework. The school size, school environment (urban or rural), type of school (general or special school), and professional development procedures at school level were taken into consideration.

Other studies (Leithwood \& Jantzi, 2009; Bellibas et al., 2016; McNeely, Nonnemaker \& Blum, 2002) have investigated the relation between school size and PLC. The majority found that in smaller schools there is a greater sense of community and cohesion and that's why they could sustain stronger PLCs. The school environment can also be an 
influencing factor. Wang et al. (2017) found differences between rural and urban schools PLC, rural schools being smaller can have stronger PLCs. Special schools have a stronger culture of collaboration (Waldron \& Mcleskey, 2014) thus the school type could have an impact on the PLC. The research on professional development practices (Chapman \& Muijs, 2013; Ho, Lee \& Teng, 2016; Blackburn \& Williamson, 2015) established an important link between PD at school level and PLC.

To our knowledge no research on the specificity of Romanian PLCs' was yet published. Most articles focus on traditional PD for pre-service (Potolea \& Toma, 2015) or university teachers (Duță \& Rafaila, 2014).

Our research aims to investigate the characteristics of Romania PLCs and study if in Romania the contextual factors described above have the same influence on PLC as in other countries and to which extent.

\section{Methodology}

Based on the above arguments the following research question was advanced:

Which contextual and individual factors determine the specificity of Romanian professional learning communities (PLCs)?

\section{Research hypotheses}

1. Peer-review is the best perceived PLC dimension.

2. There will be a negative correlation between school size and the perceived PLC.

3. There will be a positive correlation between professional development procedures and the perceived PLC.

4. There will be a difference in perceived PLC between teachers from rural and urban schools.

5. There will be a difference in perceived PLC between teachers from special and general schools.

6. There will be a correlation between personality factors and the perceived PLC.

\section{Participants and procedure}

Data were collected from a convenience sample made up of 253 Romanian school teachers from different levels, types of education and specialities (Table 1). The age of participants ranged from 25 to 60 years $(M=40.83, S D=8.71)$. Participants were $21(8.3 \%)$ men and $232(91.7 \%)$ women. The teaching tenure of participants ranged from 3 to 35 years $(M=16.93, S D=9.52)$. The participants were from 16 different counties, teaching in urban (86.2\%) and rural (13.8\%) schools. From all participants 150 (59.3\%) teach in general education and $103(40.7 \%)$ in special education schools. There were 69 primary teachers (27.3\%), 66 secondary and tertiary teachers (26.1\%), 49 special educators (19.4\%), 37 psychologists (14.6\%), 17 education specialists (6.7\%) and 15 preschool teachers $(5.9 \%)$. 
Table 1

Descriptive summary of the participants

\begin{tabular}{lcr}
\hline Category & Frequency & $\%$ \\
\hline Gender & 21 & \\
Male & 232 & 8.3 \\
Female & & \\
School environment & 218 & 86.2 \\
Urban & 35 & 13.8 \\
Rural & & \\
School type & 150 & 59.3 \\
General education & 103 & 40.7 \\
Special education & & \\
Major & 69 & 27.3 \\
Primary education & 66 & 26.1 \\
Secondary and tertiary education & 49 & 19.4 \\
Special education & 37 & 14.6 \\
Psychology & 17 & 6.7 \\
Education specialist & 15 & 5.9 \\
Preschool education & &
\end{tabular}

Two online questionnaires and a demographic survey were distributed to 1600 teachers from all Romanian regions. There was also a letter where the aims and the conditions of the study were explained. The teachers' answers indicated their agreement to be part of the study. 253 responses were received.

\section{Research instruments}

The survey combined two questionnaires - School Professional Staff as Learning Community Questionnaire (SPSLCQ) and International Personality Items Pool (IPIP 50) and a survey for school demographics and professional development practices.

School Professional Staff as Learning Community Questionnaire (SPSLCQ), developed by Hord (1996), was used to assess teachers' perceptions about their school as a learning community. There are five dimensions: shared leadership, shared vision, collective creativity, peer review, and supportive conditions/capacities. It is a 17 item instrument with a 5 point Likert response scale. SPSLCQ was not yet validated on Romanian population. The agreement for SPSLCQ usage for this study was obtained from the developer (Southwest Educational Development Laboratory, SEDL, merged with American Institute for Research, AIR). The Romanian form was obtained after a Romanian translation followed by a back to English translation was approved by The Legal Comity of AIR. In the result section, we will present the validation procedure that we undertake for SPSLCQ on Romanian population. 
Personality dimensions were assessed with the International Personality Items Pool (IPIP 50-Goldberg, 1999). Based on the Big Five model, the instrument measures the five dimensions of personality: Openness, Extraversion, Emotional Stability, Conscientiousness and Agreeableness. Teachers were asked to respond on a 5-point Likert scale that ranged from 1 (strongly disagree) to 5 (strongly agree). The instrument was adapted to the Romanian culture by Rusu, Maricuţoiu, Macsinga, Vîrgă, \& Sava (2012). The Alpha Cronbach coefficient value was found satisfactory (between .73 for agreeableness and .84 for extraversion and emotional stability).

The school demographics and professional development practices were investigated with a survey consisting of 16 questions about the size and school type, number of students in the classroom, number of teachers in the methodical committees, number of meetings during a school year, the domains of collaboration, and 8 questions about teachers' continuing professional development practices at school level.

\section{Results}

This study was designed to determine teachers' perceptions about the characteristics of Romanian PLCs` at-school-level. To do so in a valid manner, firstly we need to validate the School Professional Staff as Learning Community Questionnaire (SPSLCQ) on Romanian population.

SPSLCQ was developed by Hord (1996) as an instrument "that can be used as a screening, filtering, or assessment tool to ascertain the maturity of staff as a learning community" (Hord, Meehan, Orletsky, \& Sattes, 1999, p.3). Other mentioned purposes for the instrument are: use in diagnosis of the implementation space of a PLC in a given school and in assessing the sustainability of an intervention to implement a PLC in a new school, as well as in research studies. The instrument was included by Blitz and Schulman (2016) in a compilation of 49 instruments used for assessing the performance of a PLC.

The validity of the instrument was presented only in terms of internal consistency Cronbach`s Alpha for the entire scale of .92, test-retest reliability of .94 and concurrent validity with School Climate Questionnaire of .82 (Hord et al., 1999). A subsequent research for assessing SPLCQ validity presents Cronbach's Alpha of .93 and all measures of internal reliability significant at the .0001 level (Meehan, Orletsky, \& Sattes, 1997).

Other researchers used SPSLCQ in their studies but do not re-assess the validity of the instrument. Most of them (Yarbrough, 2010; Shetzer, 2011; Kohl, 2014, Topper, 2016; Higgins, 2016) only present the reliability coefficients reported by the developers, others verify alpha Cronbach`s per entire scale and per factors (Cassity, 2012; Spiller, 2013) and some consider SPSLCQ as a valid instrument that does not need more validation and do not present validity data at all (Boone, 2014).

Because SPSLCQ is not yet validated on Romanian population we conducted a validity analysis for the questionnaire, assessing reliability coefficients and conducting a Confirmatory Factor Analysis (CFA). 
We assessed the normality of the data set for the SPSLCQ total score and subscales. Teachers ' perception about school as a PLC was normally distributed, with skewness of $.79(S E=.15)$ and kurtosis of .32 ( $S E=.30)$. Four subscales were also normally distributed: shared leadership with skewness of $-.92(S E=.15)$ and kurtosis of .31 (SE=.30); collective creativity with skewness of $-.79(S E=.15)$ and kurtosis of $.26(S E=.30)$; peer review with skewness of -.27 $(S E=.15)$ and kurtosis of $-.74(S E=.30)$ and supportive conditions with skewness of -.65 (SE=.15) and kurtosis of -.18 (SE=.30). Shared vision subscale was nonnormally distributed, with skewness of -1.31 ( $S E=.15)$ and kurtosis of 2.04 ( $S E=.30)$.

A reliability analysis for the entire scale and per subscale (Table 2) was conducted. Internal reliability exceededs $>0.80$ for all subscales. The SPSLCQ was found to be highly reliable (17 items, $\alpha=.95$ ). Cronbach's $\alpha$ per subscales ranged from .81 to .93 indicating a good reliability per scale and per subscales.

Table 2:

Reliability Coefficients for SPSLCQ and its subscales

\begin{tabular}{lccc}
\hline & Mean & SD & Cronbach's $\alpha$ \\
\hline PLC & 3.79 & 0.82 & 0.95 \\
Shared leadership & 3.69 & 1.0 & 0.87 \\
Shared vision & 4.15 & 0.79 & 0.81 \\
Collective creativity & 3.77 & 0.94 & 0.93 \\
Peer-review & 3.41 & 1.10 & 0.89 \\
Supportive conditions & 3.77 & 0.93 & 0.90 \\
\hline
\end{tabular}

A Pearson correlation matrix between SPSLCQ items was calculated. The correlation matrix was constructed using SPSS 19. All items correlate strongly with each other, from .39 to .85 .

Also, a split-half reliability analysis was conducted. Guttman Split-Half Coefficient was .92, indicated a good internal consistency of the scale. The Part 1 of the scale`s items consisted of 9 items $(\alpha=.93)$, and The Part 2 of the scale`s items consisted of 8 items $(\alpha=.92)$.

Originally, Hord (1996) presented a five factors model, but Meehan et al. (1997) report that the best solution for the factor analysis data is a unitary factor, consisting of all 17 items of the questionnaire.

We tested a Replication of original SPSLCQ model with one factor, as suggested by Meehan et al. (1997) but also the original model with 5 factors, through Confirmatory Factor Analysis (CFA) using Jamovi version 0.2.9.8.

In order to test the model, we considered Model Chi Square $(\chi 2$, p-value $>0.05$ for the null hypothesis) relative chi-square ( $\chi 2$ /df) values lower than 5 (Arbuckle, 2007); 
Comparative Fit Index (CFI) values higher than .90 (CFI $\geq .90$ ), and Root Mean Square Error of Approximation (RMSEA) lower than .08 (RMSEA < 0.08) (Hooper, Coughlan, Mullen, 2008).

Table 3

Test for Exact Fit for SPSLCQ in one and five factors models

\begin{tabular}{lccc}
\hline Model & $\chi^{2}$ & $\mathrm{df}$ & $\mathrm{P}$ \\
\hline One-factor & 952 & 119 & $<.001$ \\
Five-factor & 501 & 109 & $<.001$ \\
\hline
\end{tabular}

The original five-factor structure of SPSLCQ adequately fit the sample $(\chi 2 / d f=4.62$, $\chi^{2}=501, p<0.01$ for the null hypothesis) but the one-factor presents lower exact fit coefficients $\left(\chi 2 / d f=8, \chi^{2}=952, p<0.01\right)$ (Table 3 ).

Model fit statistics for both models is reported in Table 4.

Table 4

Test for Exact Fit for SPSLCQ one-factor and five-factor models

\begin{tabular}{llllll}
\hline & & & & \multicolumn{2}{c}{ RMSEA 90\% CI } \\
\cline { 5 - 6 } Model & CFI & TLI & RMSEA & Lower & Upper \\
\hline One-factor & 0.790 & 0.760 & 0.166 & 0.157 & 0.176 \\
Five-factor & 0.901 & 0.877 & 0.119 & 0.109 & 0.130 \\
\hline
\end{tabular}

The five-factor model fit adequately CFI $=0.90, \mathrm{TLI}=0.87, \mathrm{RMSEA}=0.11$, proving acceptable fit of the model. The one-factor model did not fit to the same extent as the five-factor model, $\mathrm{CFI}=0.79$, TLI $=0.76, \mathrm{RMSEA}=0.16$.

Although the factors seemed to have high correlations (Table 5), they were not high enough to combine all factors into one single factor. Therefore, in the subsequent analyses each subscale of the SPSLCQ was considered as a unique factor.

Table 5

Correlation matrix for SPSLCQ five factors

\begin{tabular}{lccccc}
\hline & 1. & 2. & 3. & 4. & 5. \\
\hline 1.Shared leadership & - & 0.662 & 0.633 & 0.623 & 0.527 \\
2.Shared vision & & - & 0.774 & 0.721 & 0.572 \\
3.Collective creativity & & & - & 0.810 & 0.673 \\
4.Supportive conditions & & & & - & 0.678 \\
5.Peer-review & & & & & - \\
\hline
\end{tabular}

To determine if there is difference between the five dimensions of PLC in teachers perception the means and standard deviations for the PLCs`dimensions were calculated. The obtained hierarchy of PLCs' dimensions (Figure 1) is: shared vision $(M=4.15$, 
$S D=.79)$, collective creativity $(M=3.77, S D=.94)$, supportive conditions/capacities $(M=3.77, S D=.93)$, shared leadership $(M=3.68, S D=1.05)$ and peer review $(M=3.41$, $S D=1.09)$. In the research hypothesis we stated that peer-review is the best perceived dimension. In the obtained hierarchy peer-review is the lowest ranked from all five dimensions. The first hypothesis is rejected.

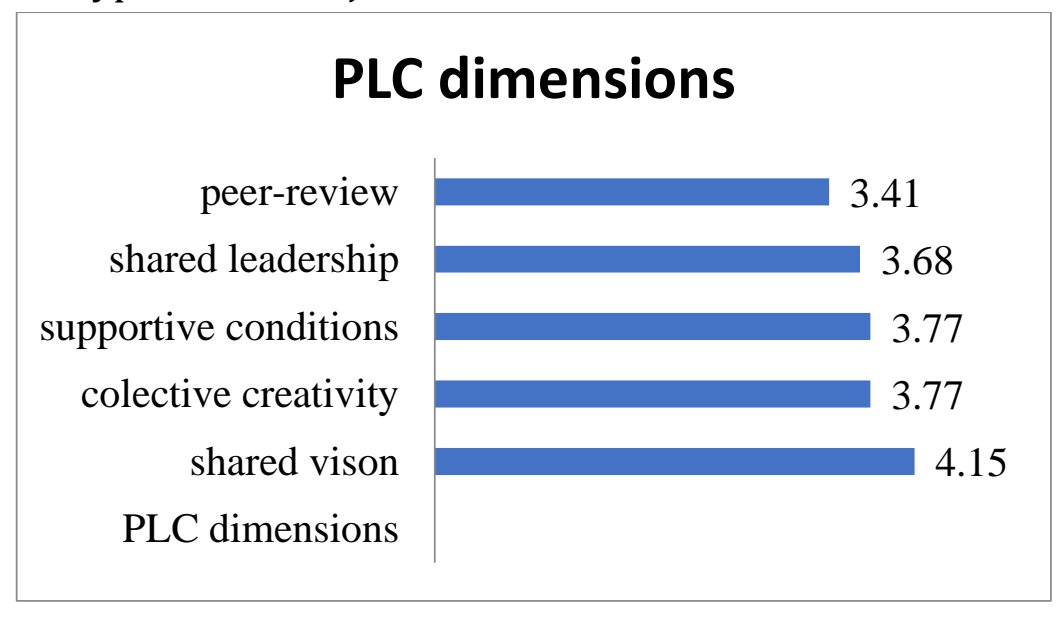

Figure 1: Bar chart for PLC dimensions

To determine if there is a negative correlation between school size and the perceived PLC we calculated Spearman`s rho at one-tailed level between the school size (measured by the number of students) and PLC's dimensions (Table 6). The school size negatively correlated with perceived PLC $r_{s}$ (253) =-.17, $p=0.02$. Also, significant negative correlations were obtain between school size and collective creativity $r_{s}(253)=-.21$, $p=.00$ and school size and supportive conditions $r_{s}(253)=-.19, p=0.001$. The research hypothesis 2 is accepted. However, the effect size, $r^{2}=0.02$, indicates a poor coefficient of determination between school size and perceived PLC, school size explain only $2.89 \%$ of PLC variance.

\section{Table 6}

Correlations Between Five PLC Dimensions and School Size

\begin{tabular}{lllllll}
\hline Measure & PLC & $\begin{array}{l}\text { Shared } \\
\text { leadership }\end{array}$ & $\begin{array}{l}\text { Shared } \\
\text { vision }\end{array}$ & $\begin{array}{l}\text { Collective } \\
\text { creativity }\end{array}$ & $\begin{array}{l}\text { Peer- } \\
\text { review }\end{array}$ & $\begin{array}{l}\text { Supportive } \\
\text { conditions }\end{array}$ \\
\hline School size & $-.17^{* *}$ & -.06 & $-.14^{*}$ & $-.21^{* *}$ & -.10 & $-.19^{* *}$ \\
\hline
\end{tabular}

**. Correlation is significant at the 0.01 level (1-tailed).

To determine if there is a positive correlation between professional development procedures at school level and the perceived PLC we calculated Pearson Correlation at one-tailed level between the professional development procedures (measured by an eight-item survey) and PLC dimensions (Table 7). The professional procedures at school level positively correlate with perceived PLC $r(253)=.36, p=.00$ Also, significant correlations were obtained between professional development procedures at school level and all PLC dimensions: shared leadership $r(253)=.35, p=.00$, shared vision $r(253)$ $=.22, p=.00$, collective creativity $r(253)=-.36, p=.00$, peer-review $r(253)=.31, p=.00$ and 
supportive conditions $r(253)=.31, p=0.001$. Research hypothesis 3 is accepted. However, the effect size, $r^{2}=0.12$, indicates a relatively poor coefficient of determination between professional development procedures and perceived PLC, professional development procedures explain only $12.25 \%$ of PLC variance.

Table 7

Correlations Between Five PLC Dimensions and Professional Development Procedures at School Level

\begin{tabular}{lllllll}
\hline Measure & PLC & $\begin{array}{l}\text { Shared } \\
\text { leadershi } \\
\mathrm{p}\end{array}$ & $\begin{array}{l}\text { Share } \\
\mathrm{d} \\
\text { vision }\end{array}$ & $\begin{array}{l}\text { Collective } \\
\text { creativity }\end{array}$ & $\begin{array}{l}\text { Peer- } \\
\text { revie }\end{array}$ & $\begin{array}{l}\text { Supportiv } \\
\mathrm{w}\end{array}$ \\
& & & & $\begin{array}{l}\text { condition } \\
\mathrm{s}\end{array}$ \\
\hline $\begin{array}{l}\text { Professionalization } \\
\text { procedures }\end{array}$ & $.36^{* *}$ & $.35^{* *}$ & $.22^{* *}$ & $.36^{* *}$ & $.31^{* *}$ & $.31^{* *}$ \\
\hline
\end{tabular}

**. Correlation is significant at the 0.01 level (1-tailed).

To determine if there is a difference in perceived PLC between teachers from rural and urban schools an independent sample t-test was conducted (Table 8). Given a violation of Levene's test for homogeneity of variances, $F(1,251)=.14, p=.70$, a t-test not assuming homogeneous variances was calculated. The results of this test indicated that there was no significant difference in perceived PLC observed between the two groups, $t(45.05)=-1.34, p=.18$. These results suggest that there is no significant difference between perceived PLC in urban schools`group $(M=63.87$; SD $=14.02)$ and rural schools` group $(M=67.37 ; S D=14.35)$. Research hypothesis 4 is rejected.

Table 8:

Independent t-test Results Comparing Urban and Rural PLC Perceptions

\begin{tabular}{lccccc}
\hline & \multicolumn{3}{c}{ Urban } & \multicolumn{3}{c}{ Rural } \\
\hline & $M$ & $S D$ & $M$ & $S D$ & -test \\
PLC & 63.87 & 14.02 & 67.37 & 14.35 & -1.34 \\
Shared leadership & 3.65 & 1.05 & 3.87 & 1.08 & -1.08 \\
Shared vision & 4.12 & .80 & 4.32 & .70 & -1.53 \\
Collective creativity & 3.73 & .94 & 3.99 & .88 & -1.59 \\
Peer-review & 3.37 & 1.09 & 3.65 & 1.09 & -1.43 \\
Supportive conditions & 3.75 & .92 & 3.87 & 1.00 & -.66 \\
\hline
\end{tabular}

To determine if there is a difference in perceived PLC between teachers from general and special education an independent sample t-test was conducted (Table 9). Given a violation of Levene's test for homogeneity of variances, $F(1,251)=2.12, p=.14$, a t-test not assuming homogeneous variances was calculated. The results of this test indicated that there was no significant difference in perceived PLC observed between the two groups, $t(240.96)=-.99, p=.32$. These results suggest that there is no significant difference between perceived PLC in general education schools' group $(M=63.65$; SD $=$ 
15.02) and special schools' group $(M=65.38 ; S D=12.61)$. Research hypothesis 5 is rejected.

Table 9:

Independent t-test Results Comparing General and Special Education Teachers` PLC

Perceptions

\begin{tabular}{lccccc}
\hline & $\begin{array}{c}\text { General } \\
\text { education }\end{array}$ & & \multicolumn{3}{l}{ Special education } \\
& $M$ & $S D$ & $M$ & $S D$ & t-test \\
PLC & 63.65 & 15.02 & 65.38 & 12.61 & -.99 \\
Shared leadership & 3.73 & 1.05 & 3.61 & 1.05 & .88 \\
Shared vision & 4.09 & .85 & 4.22 & .67 & -1.32 \\
Collective creativity & 3.69 & .99 & 3.87 & .85 & -1.55 \\
Peer-review & 3.42 & 1.13 & 3.38 & 1.00 & .27 \\
Supportive conditions & 3.70 & .97 & 3.86 & .86 & -1.29 \\
\hline
\end{tabular}

To determine if any individual factors correlate with the perceived PLC a Pearson Correlation between the Big Five personality factors and perceived PLC was conducted (Table 10).

Table 10

Correlations Between Big Five Personality Factors and Perceived PLC

\begin{tabular}{llllll}
\hline Measure & Openness & Extraversion & Agreeableness & Conscientiousness & $\begin{array}{l}\text { Emotional } \\
\text { Stability }\end{array}$ \\
\hline Perceived & -.02 & .00 & .04 & .11 & .02 \\
PLC & & & & & \\
\hline
\end{tabular}

None of the personality factors significantly correlate with PLC (Table 10): openness $r(253)=-.02, p=.70$, extraversion $r(253)=.00, p=.91$, agreeableness $(253)=.04, p=.44$, emotional stability, $r(253)=.02, p=.70$. Conscientiousness correlates the most with PLC $r(253)=.11, p=.06$ but not at a significant level. Research hypothesis 6 is rejected.

\section{Discussion and conclusions}

In the context of a growing need of highly qualified teachers we aimed to investigate which of the PLC's dimensions are most representative for Romanian schools and observe what individual and organizational factors influence it.

Our research is embedded in the PLC research agenda proposed by Hairon et al. (2015). Specifically, it addresses the third research gap identified: the lack of theorization on the PLC context. Also, through our effort we can add knowledge to understanding the cultural specificity of PLCs, by analysing the specific contextual factors that can influence Romanian PLCs. 
We designed a quantitative methodology, in which 253 teachers responded on-line to 2 questionnaires: SPSLCQ and IPIP-50 and a survey for school demographics and professional development practices.

SPSLCQ has not been previously validated on Romanian population, so a reliability analysis and a CFA were conducted. Very good internal consistency coefficients were obtained for the entire scale (17 items, $\alpha=.95$ ) and per factors.

Originally, Hord (1996) presented a five factors model, but Meehan et al. (1997) report that the best solution for the factor analysis data is a unitary factor, consisting of all 17 items of the questionnaire. We tested a replication of the original SPSLCQ model with one factor, but also the original model with 5 factors, through Confirmatory Factor Analysis (CFA). Unlike the one-factor model, the five-factor model indicated a better model fit in which all fit indices were closer to the desired criteria. Therefore, in the subsequent analyses each subscale of the SPSLCQ was considered as a unique factor.

The first purpose of our research was to identify the specificity of Romanian PLCs` in terms of the best perceived PLC dimension. We presumed that peer-review is the most well-perceived dimension of all five dimensions, also being the most traditional in the Romanian context. In terms of professional development practices, class observation and analysis of teachers' work are some of the most used (OM 3367/2017 These traditional PD practices characteristic of the Romanian context correspond in the SPSLCQ to the concept of peer review. Nevertheless, the analyzed data shows that shared vision is one of the most appreciated features. These findings are congruent with the results of other studies. (Spiller, 2013; Lokman Mohd Tahir, 2013; Ward, 2015; Bellibas, Bulut, Gedik, 2016; Wilson, 2016). The items of the shared vision scale refer to a common vision about improvement, centred on students, learning and teaching. So, the teachers perceptions indicate a common aim, centred on students' learning. However, the shared vision subscale was the only one of the scales non-normally distributed, with skewness of -1.31 $(S E=.15)$ and kurtosis of $2.04(S E=.30)$. Further research is needed to clarify if the responses for this dimension were due to the social desirability response bias or not. In spite of our assumption, the least represented PLC dimension was feed-back; teachers do not observe each-others' classes, nor do they work with each other in teaching. Through subsequent qualitative research, we need to clarify if teachers emphasize more the student-centred dimension of the PLC, rather than the collaborative one. Traditionally, in Romania teachers are used to being alone throughout the teaching process, in planning, implementing and evaluating the teaching.

The second purpose of this research was to identify the contextual factors that impact the Romanian PLC. From the organizational-contextual factors we examined the school size, professional development procedures at school level, school type (mainstream or special) and school environment (rural or urban).

Studies (Leithwood, Jantzi, 2009; Bellibas et al., 2016) have shown that in smaller schools there is a greater sense of community between teachers and that smaller schools 
provide more interaction and participation opportunities for teachers (Newman et al., 2006).

In our findings, school size negatively correlates with perceived PLC (r (253) =-.17, $p=0.02$ ), which means that the bigger the school is, the lower the perception about PLC. These findings are similar with other author's research (McNeely, Nonnemaker, Blum, 2002; Leithwood, Jantzi, 2009; Bellibas et al., 2016). However, school size explains only $2.89 \%$ of PLC variance, so is not a determinant factor. In large schools the communities of professional development can be divided in smaller groups of teachers to increase the power of collaborative learning practices.

We also assumed that schools with strong professional development procedures are more likely to develop better collaboration for teaching and learning practices. Chapman and Muijs (2013) found that administrators that imposed strong professional development practices at their schools fostered a collaborative environment and increased students`outcomes.

Our results show that professional development practices positively correlate with the perceived PLC $(r(253)=.36, p=.00)$. If good professional practices are being implemented in the school, the PLC is stronger. The professional development procedures explain $12.25 \%$ of PLC. The results are congruent with other findings. Ho et al. (2016) found that there is a strong relationship between PLC and school-level teachers' qualification. Thomson and Holloway (1997) ascertain that educational change occurs in schools where teachers support each other and that staff development and educational change are interdependent. Blackburn and Williamson (2015) consider that the most effective schools are those in which teachers believe in the power of professional development.

So, for stronger PLCs school administration have to implement at-school-level professional development procedures.

The relationship between PLC and school environment was examined by other authors (Wang, Wang, Li, \& Li, 2017) reporting qualitative differences between schools. Rural schools are often small schools with teachers from the local community. They come from traditional communities where collaboration and helping each other are adopted values. Urban schools are often larger and with a not so high sense of cohesion.

In special schools, practices of collaboration are more common than in general education. Special educators work in the case management framework and are used to finding solutions together. In special education, teachers participate in professional development and decide which practices best fit the student needs (Hartman, 2011).

Non- significant differences were obtained between PLC at urban and rural schools $(t(45.05)=-1.34, p=.18)$ and between general and special education schools $(t(240.96)=-$ $.99, p=.32$ ). Rural and special schools record better PLC levels but not significant. Similar results were reported by other authors. Hallinger and Liu (2016) found no significant differences between urban and rural schools, albeit weaker PLC was found in rural schools. 
From the individual factors we take into consideration the Big Five` personality factors in relation with PLC. Benoliel and Schechter (2017) advanced that Big Five personality traits have an influence on PLC through tendencies for relation building and knowledge sharing.

In our findings, none of the personality factors significantly correlates with PLC, however conscientiousness is the most influential factor $(r(253)=.11, p=.06)$.

In conclusion, Romanian PLCs' do not significantly differ from those in other countries. Our findings are similar with research conducted in other national contexts, the most representative PLC dimension being a shared vision, centred on students` learning. The organizational factor which explains best the PLC is the existence of strong school-level professional development procedures. School size is a factor that correlates with PLC but not very strongly, the smaller the school, the stronger the PLC is. For stronger PLCs, teachers must be divided in small groups for professional learning. PLCs do not differ in terms of school environment and school type. The personality factor that correlates the most with PLC is conscientiousness, but the correlation is non-significant.

\section{Limitations of the study and further research directions}

The main limitation of this research is the number of organizational and individual factors taken into consideration. From our findings the best explanation for PLC with only $12.25 \%$ of the variance explained are the professional development practices at schoollevel. Other factors to be analysed can be the managing style of the school administration, the theoretical approach to learning promoted by teachers or school culture. Another limitation of the study is the relatively small number of participants; an increase in numbers of responding teachers must be achieved. Also, this study did not assess specific schools and did not group the responses per school to obtain a clearer image of the PLC. In further research, we intend to deepen the knowledge on this subject through a mixed methods study design, combining qualitative and quantitative research focused on analysing the effects of PLCs on student learning.

\section{Authorship statement}

The authors of this paper take public responsibility for the content and have had equal contribution in concept development, design, analysis, writing, or revision of the manuscript.

\section{Acknowledgments:}

The authors express sincere gratitude to Professor habil. Simona Sava for her scientific support and inspiring discussions; we thank Daniel Iancu and Velibor Mladenovici for the useful feedback of the methodological section; we thank Leyla Safta Zecheria for the English text revision. 


\section{References}

Arbuckle, J. (2007). Amos ${ }^{T M} 18$ user's guide. Chicago, IL: SPSS.

Bellibas, M.S., Bulut, O., \& Gedik, S. (2016). Investigating professional learning communities in Turkish schools: the effects of contextual factors. Professional Development in Education. doi: $10.1080 / 19415257.2016 .1182937$

Benoliel, P., \& Schechter, C. (2017). Is it personal? Teacher`s personality and the principal`s role in professional learning communities. Improving schools, 1-14. doi.org/10.1177/1365480217703725

Berry, A. L. (2011). Effecting Change: Intervention for Culturally and Linguistically Diverse. Huntington Beach, CA: Shell Educational Publishing.

Blackburn, B., \& Williamson, R. (2015). Five tools for Collaborative Professional Development. Curriculum in context. Retrieved from http://wsascd.org/wp-content/uploads/3-Five-Tools-for-CollaborativeProfessional-Development1.pdf

Blitz, C. L., \& Schulman, R. (2016). Measurement instruments for assessing the performance of professional learning communities. Regional Education Library. Retrieved from https://ies.ed.gov/ncee/edlabs/regions/midatlantic/pdf/REL_2016144.pdf

Bolam, R., McMahon, A., Stoll, L., Thomas, S., Wallace, M., Greenwood, A., ... \& Smith, M. (2005). Creating and sustaining effective professional learning communities. Research Report 637. London: DfES and University of Bristol. Retrieved from https://dera.ioe.ac.uk/5622/1/RR637.pdf

Boone, S. (2014). Using Organizational Learning to Increase Operational and Conceptual Mental Models Within Professional Learning Communities. Journal of Psychological Issues in Organizational Culture, 5(3), 85-99. doi:10.1002/jpoc.21152

Cassity, A.H. (2012). Relationships among perceptions of professional learning communities, school academic optimism, and student achievement in Alabama middle and high schools. DAI-A 74/02(E), Dissertation Abstracts International. Retrieved from https://pqdtopen.proquest.com/doc/1095714772.html?FMT=AI

Chapman, C., \& Muijs, D. (2013). Does school-to-school collaboration promote school improvement? A study of the impact of school federations on student outcomes. School Effectiveness and School Improvement. An International Journal of Research, Policy and Practice, 25(3), 351-393. doi: $\underline{10.1080 / 09243453.2013 .840319}$

Darling-Hammond, L. \& Richardson, N. (2009). Research Review/Teacher Learning. What Matters. Educational leadership, 66(5), 46-53. Retrieved from

http://outlier.uchicago.edu/computerscience/OS4CS/landscapestudy/resources/Darling-Hammondand-Richardson-2009.pdf

Diehl, D., \& Diehl, D. (2019). Research Papers in Education The multiplexity of professional learning communities: exploring the co-evolution of teacher social networks exploring the co-evolution of teacher social networks. Research Papers in Education, 1-17. doi: 10.1080/02671522.2019.1615115

Doğan, S., Pringle, R., and Mesa, J., 2016. Professional development in education the impacts of professional learning communities on science teachers' knowledge, practice and student learning: A review. Professional development in education, 42, 569-588. doi:10.1080/19415257.2015.1065899

Doğan, S. \& Adams, A. (2018): Effect of professional learning communities on teachers and students: reporting updated results and raising questions about research design. School Effectiveness and School Improvement, 1-26. doi: 10.1080/09243453.2018.1500921

Doppelt, Y., Schunn, C., Silk, E., Mehalik, M., Reynolds, B., \& Ward, E. (2009). Evaluating the impact of a facilitated learning community approach to professional development on teacher practice and student achievement. Research in Science, and Technology Education, 27(3), 339-354. Retrieved from https://www.learntechlib.org/p/166774/.

DuFour, R., \& Eaker, R. (1998). Professional Learning Communities at Work: Best Practices for Enhancing Student Achievement. Bloomington, IN: National Educational Service. 
DuFour, R. (2004). What Is a Professional Learning Community? Schools as Learning Communities, Association for Supervision and Curriculum Development. Retrieved from http://www.ascd.org/publications/educational-leadership/may04/vol61/num08/What-Is-aProfessional-Learning-Community\%C2\%A2.aspx

DuFour, R., DuFour, R., Eaker, R., Many, T., Mattos, M. (2016), Learning by Doing. A Handbook for Professional Learning Communities at work, Solution Tree Press

Dumitriu, C., Dumitriu, G., \& Timofte, I. (2014). Teachers' professional development and career advancement. Limitations of the current model of professional competences assessment. Procedia Social and Behavioral Sciences, 116, 864 - 868. Retrieved from https://core.ac.uk/download/pdf/82259431.pdf

Duță, N., \& Rafaila, E. (2014). Importance of the lifelong learning for professional development of university teachers - needs and practical implications. Procedia Social and Behavioral Sciences 127, 801-806. doi: 10.1016/j.sbspro.2014.03.358

Eurydice. (2018). Dezvoltarea profesională continuă a cadrelor didactice din educaţia timpurie şi învăţământul preuniversitar. Retrieved from https://eacea.ec.europa.eu/nationalpolicies/eurydice/content/continuing-professional-development-teachers-working-earlychildhood-and-school-education-61_ro

European Commission. (2017). Education and Training Monitor 2017, Romania. Luxembourg: Publications Office of the European Union. Retrieved https://ec.europa.eu/education/sites/education/files/monitor2017-ro_en.pdf

Goldberg, L. R. (1999). A broad-bandwidth, public domain, personality inventory measuring the lowerlevel facets of several five-factor models. In I. Mervielde, I. Deary, F. De Fruyt, \& F. Ostendorf (Eds.). Personality Psychology in Europe, Vol. 7 (pp. 7-28). Tilburg, The Netherlands: Tilburg University Press.

Gore, J. Lloyd, A., Smith, M., Bowe, J., Ellis, H. \& Lubans, D. (2017). Effects of professional development on the quality of teaching: Results from a randomised controlled trial of Quality Teaching Rounds. Teaching and Teacher education, 68, 99-113. doi: 10.1016/j.tate.2017.08.007

Hairon, S., Wee Pin Goh, J., Siew Kheng Chua, C. \& Wang, L. (2015): A research agenda for professional learning communities: moving forward, Professional Development in Education, 1-15. doi: 10.1080/19415257.2015.1055861

Hallinger, P., \& Liu, S. (2016). Leadership and teacher learning in urban and rural schools in China: Meeting the dual challenges of equity and effectiveness. International Journal of Educational Development, 5, 163-173. doi: 10.1016/j.ijedudev.2016.10.001

Hargreaves, A. \& O`Connor, M.T. (2018). Leading collaborative professionalism. Centre for Strategic Education (CSE) seminar series paper 274, April 2018. Retrieved from http://www.andyhargreaves.com/uploads/5/2/9/2/5292616/seminar_series_274-april2018.pdf

Hartman, E.L. (2011). Building Professional Learning Communities In Special Education Through Social Networking: Directions For Future Research. I-manager's Journal on School Educational Technology, 7(2), 30-38. doi: 10.26634/jsch.7.2.1651

Higgins, K. (2016). An Investigation of Professional Learning Communities in North Carolina School Systems. Journal of Research Initiatives, 2(1), 1-21. Retrieved from http://digitalcommons.uncfsu.edu/jri/vol2/iss1/9

Ho, D., Lee, M., \& Teng, Y. (2016). Exploring the relationship between school-level teacher qualifications and teachers' perceptions of school-based professional learning community practices. Teaching and Teacher Education, 54, 32-43. doi: 10.1016/j.tate.2015.11.005

Hooper, D., Coughlan, J., Mullen, M (2008) Structural Equation Modelling: Guidelines for Determining Model Fit. Electronic. Journal of Business Research Methods, 6(1), 53-60.

Retrieved from: 
https://www.researchgate.net/publication/254742561_Structural_Equation_Modeling_Guidelines ff or Determining Model Fit

Hord, S. (1996). School professional staff as learning community [Survey]. Austin, TX: Southwest Educational Development Laboratory.

Hord, S.M. (1997). Professional Learning Communities: Communities of Continuous Inquiry and Improvement. Southwest Educational Development Laboratory. Retrieved from http://www.sedl.org/pubs/change34/plc-cha34.pdf

Hord, S. M., Meehan, M. L., Orletsky, S., \& Sattes, B. (1999). Assessing a school staff as a community of professional learners. Issues about Change, 7, 1-8. Retrieved from http://www.sedl.org/change/issues/issues71/Issues Vol7 No1 1999.pdf

Kohl, K.T. (2014). Teachers' Perceptions of Becoming a Professional Learning Community. Walden Dissertations and Doctoral Studies. Retrieved from https://scholarworks.waldenu.edu/cgi/viewcontent.cgi?article=3840\&context=dissertations

Leithwood, K., \& Jantzi, D. (2009). A review of empirical evidence about school size effects: A policy perspective. Review of Educational Research, 79(1), 464-490. doi: 10.3102/0034654308326158

Lieberman, A. (1995). Practices that Support Teacher Development: Transforming Conceptions of Professional Learning. In Stevens, F. (Ed.) Innovating and evaluating science education: NSF Evaluation Forum 1992-1994. Retrieved from https://www.nsf.gov/pubs/1995/nsf95162/nsf_ef.pdf\#page=58

Lokman Mohd Tahir, Mohd Nihra Haruzuan Mohd Said, Mohd Fazli Ali, Narina A. Samah, Khadijah Daud, Tasia Hidaya Mohta. (2013). Examining the professional learning community practices: An empirical comparison from Malaysian universities clusters. Procedia-So cial and Be havioral Scie $n$ ces $97,105-113$

Lomos, C., Hofman, R.H. \& Bosker, R.J. (2011) Professional communities and student achievement - a meta-analysis. School Effectiveness and School Improvement, 22(2), 121-148. doi: 10.1080/09243453.2010.550467

Loucks-Horsley, S., \& Matsumoto, C. (1999). Research on Professional Development for Teachers of Mathematics and Science: The State of the Scene. School Science and Mathematics, 99(5), 258-271. doi:10.1111/j.1949-8594.1999.tb17484.x

McNeely, C.A., Nonnemaker, J.M., \& Blum, R.W. (2002). Promoting student connectedness to school: evidence from the national longitudinal study of adolescent health. Journal of School Health, 72, 138146. doi: 10.1111/j.1746-1561.2002.tb06533.x

Meehan, M. L., Orletsky, S. R., \& Sattes, B. (1997). Field test of an instrument measuring the concept of professional learning communities in schools. Charleston, WV: Appalachia Educational Lab. Retrieved https://files.eric.ed.gov/fulltext/ED433358.pdf

Newman, M., Garrett, Z., Elbourne, D., Bradley, S., Noden, P., Taylor, J., et al. (2006). Does secondary school size make a difference? A systematic review. Educational Research Review,1(1), 41-60. doi: 10.1016/i.edurev.2006.03.001

Ordin de Ministru 3367/2017. Ordin de ministru privind modificarea si completarea Metodologiei privind formarea continua a personalului din invatamantul preuniversitar, aprobata prin Ordinul ministrului educatiei, cercetarii, tineretului si sportului nr. 5561/2011. Retrieved from http://www.uaiasi.ro/ro/files/DPPD/legislatie/Ordin-3367-2017.pdf

Potolea, D., \& Toma, S. (2015). The Dynamic and Multidimensional Structure of the Teachers Professional Development. Procedia - Social and Behavioral Sciences, 180, 113-118. doi:

10.1016/j.sbspro.2015.02.093

Ratts, R.F., Pate, J.L., Archibald, J.G., Andrews, S.P., Ballard, C.C. \& Lowney, C. (2015). The Influence of Professional Learning Communities on Student Achievement in Elementary Schools. Journal of Education \& Social Policy, 2(4), 51-61, Retrieved from http://www.jespnet.com/journals/Vol_2_No_4_October_2015/5.pdf 
Rusu, S., Maricuţoiu, L., Macsinga, I., Vîrgă, D., \& Sava, F. (2012). Evaluarea personalitãţii din perspectiva modelului Big Five. Date privind adaptarea chestionarului IPIP-50 pe un eşantion de studenţi români. Psihologia resurselor umane, 10 (1), 39-56. Retrieved from https://www.socpers.psihologietm.ro/PDFs/Rusu\%20et\%20al\%20(2012).pdf

Shetzer, S.D. (2011). A study of the relationship between teacher efficacy and professional learning communities in an urban high school. Dissertation and Doctoral Studies. Retrieved from http://hdl.handle.net/10657/580

Spiller, N. (2013). The relationship among professional learning communities, a response to intervention framework and mathematics scores in middle and high schools. ProQuest Dissertations and Theses. Retrieved from http://acumen.lib.ua.edu/content/u0015/0000001/0001212/u0015 0000001 0001212.pdf

Stewart, C. (2014). Transforming Professional Development to Professional Learning. Journal of Adult Education, 43(1), 28-33. Retrieved from https://files.eric.ed.gov/fulltext/EJ1047338.pdf

Stoll, L., Bolam, R., McMahon, A., Wallace M. \& Thomas, S. (2006). Professional learning communities: a review of the literature. Journal of Educational Change 7, 221-258. doi: 10.1007/s10833-006-0001-8

Stoll, L. (2010). Professional learning community. International Encyclopedia of Education, 151-157. doi: 10.1016/B978-0-08-044894-7.00435-8

Thomson, J.M., \& Holloway, D.G. (1997). Staff development procedures and a culture of collaboration in a primary school. Teacher Development, 1(2), 309-326. doi: 10.1080/13664539700200017

Topper, J. C. (2016). The Relationship between Secondary Schools' PLC Characteristics and Literacy Achievement. Electronic Theses and Dissertations. 1498. Retrieved from https://digitalcommons.georgiasouthern.edu/etd/1498

Vescio, V., Ross, D., \& Adams, A. (2008). A review of research on the impact of professional learning communities on teaching practice and student learning. Teaching and Teacher Education 24, 80-91. doi:10.1016/j.tate.2007.01.004

Waldron, N., \& Mcleskey, J. (2014). Establishing a Collaborative School Culture Through Comprehensive School Reform, (May). doi: 10.1080/10474410903535364

Wang, D., Wang, J., Li, H., \& Li, L. (2017). School context and instructional capacity: A comparative study of professional learning communities in rural and urban schools in China. International Journal of Educational Development, 52, 1-9. doi:10.1016/j.ijedudev.2016.10.009

Ward, P. (2015). Measuring Dimensions of Professional Learning Communities to Predict Secondary School Climate. Walden Dissertations and Doctoral Studies. Retrieved from https://scholarworks.waldenu.edu/cgi/viewcontent.cgi?referer=\&httpsredir=1\&article=1608\&cont ext=dissertations

Wilson, A. (2016). From Professional Practice to Practical Leader: Teacher Leadership in Professional Learning Communities. International Journal of Teacher Leadership, 7(2), 45-62. Retrieved from https://files.eric.ed.gov/fulltext/EJ1137497.pdf

Yarbrough, S. M. (2010). Efficacy of professional learning communities and their impact upon student academic outcome as perceived by local school administrators and teachers". ETD Collection for AUC Robert W. Woodruff Library. Paper 221 